International Journal of Instruction e-ISSN: 1308-1470 • www.e-iji.net

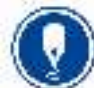

July $2021 \bullet$ Vol.14, No.3

p-ISSN: 1694-609X

pp. 929-944

Article submission code

20200901094547

Received: 01/09/2020

Revision: 04/02/2021

Accepted: 27/02/202

OnlineFirst: 23/06/2021

\title{
Pedagogical-Psychological Subjects in Teacher Education Faculties in Serbia: A Proposal of the Core Curriculum
}

\section{Ruženka Šimonji Černak}

Prof., Faculty of Education in Sombor, University of Novi Sad, Serbia, ruzenka.cernak@gmail.com

\section{Mila Beljanski}

Prof., Faculty of Education in Sombor, University of Novi Sad, Serbia, milabelj@gmail.com

This paper deals with teacher education at pedagogical faculties in Serbia. An analysis of the content of pedagogical and psychological subjects was carried out. Subjects in the current curricula for initial teacher education in seven pedagogical faculties were analyzed. The first objective is to determine whether compulsory pedagogical and psychological subjects enable students to acquire the prescribed competence standards required of teachers. The second objective is to determine if there is a basis for creating a core curriculum in the field of pedagogical and psychological sciences in the existing curricula in terms of compulsory content in all the pedagogical faculties. This content should ensure the achievement of all the competence standards of all future teachers, equally throughout Serbia. For the realization of the set goal and research questions, a method of content analysis was used, with which we analyzed the curricula of the faculty for teacher education. The results showed that the core curriculum should consist of General pedagogy, Didactics, School pedagogy, Family pedagogy and Methodology of pedagogical research in the field of pedagogical sciences. The field of psychological sciences should be represented through General psychology, Developmental psychology and Pedagogical psychology. The core curriculum can contribute to a clear and unambiguous opportunity for the teacher to acquire all the necessary competences for further work.

Keywords: core curriculum, teacher education, pedagogy, psychology, competences standards

\section{INTRODUCTION}

If we want to simply define the concept of curriculum at the level of high education, we can say that it implies a comprehensive answer to the questions "who is learning", "what and why is being learnt" and "how to learn". In other words, what kind of student population it is intended for, what is the content of the study program/module, what are

Citation: Černak, R. Š., \& Beljanski, M. (2021). Pedagogical-psychological subjects in teacher education faculties in Serbia: a proposal of the core curriculum. International Journal of Instruction, 14(3), 929-944. https://doi.org/10.29333/iji.2021.14354a 
the expected outcomes and what is the way of acquiring the expected competences of the students.

Curriculum approaches that belong to the technical, scientific paradigm are behavioral, managerial, and systems approach (Domović, 2009). The behavioral approach is the oldest and most commonly used. Its basic idea is that the goals of the learning, as well as the learning and teaching itself, are accurately and precisely defined, scientifically based and that the outcomes can be measured. The managerial approach stems from the theory of organization and approaches the curriculum more from the administrative aspect, from the aspect of managing an educational institution as an organization (Fallows \& Steven, 2000). The systems approach has evolved under the influence of system theory and is based on processes necessary for curriculum planning: areas, subjects, syllabuses, lesson planning.

One of the basic types of curriculum is the core curriculum. This term refers to subjects that are compulsory for everyone, a common core and a predetermined set of knowledge, skills and abilities required for all the students in one field of knowledge. In addition to the core curriculum, the scholarly literature also mentions integrated or problem-solving, activity curriculum and spiral curriculum (D'Elia et al., 2018; Kuiper \& Berkvens, 2013)

In the curriculum development process, at high education institutions in Serbia, we can still find the remnants of the concept "My subject". We can describe it as a phenomenon that a subject is being taught in the faculty because there is a professor who likes to have his/her "Own subject", without taking into account whether students need the subject at all to acquire certain qualifications and competences (Vukasović, 2006). The existence of the concept of "My subject" may be one of the arguments for introducing a core curriculum with clearly defined standards for the achievement of particular qualifications and competences. If there are unique competence standards for all the teachers in Serbia, there should also be unique ways to reach those competences in initial education. Teaching and learning programs at all levels of education are based on general goals and outcomes of education and upbringing, so the sole contents are no longer the goal, but they are in the function of achieving outcomes that lead to the development of competencies (Pravilnik, 2017). The National Association of Psychologists in Serbia through its Association of University Teachers of Education Psychology in Serbia is also interested in harmonizing psychological subjects through the exchange of data on literature, pre-examination obligations of students, exams and assessment methods (Plan rada sekcije unverzitetskih nastavnika psihologije obrazovanja, 2018). As an example, we can mention the pedagogical faculties in the Slovak Republic, where there is a core curriculum which represents a common basis at all faculties that educate future teachers (Kosová et al., 2015). Based on the Strategy of education development in Serbia (Strategija razvoja obrazovanja, 2012), we also indicated pedagogical goals and restructuring higher learning facilities, as well as the needs for the unification of studying pedagogical subjects and the modernization of study programs of faculties in Serbia with the goal to strengthen research activities, intra-university and inter-university connection and cooperation, and also the needed, 
unified competencies for the job market.Therefore, it is advisable to consider the need for a clearly and precisely defined common core curriculum in teacher education, starting from the end, from desirable competences.

In order to achieve more successful and qualitative complex goals of the modern curriculum and the demands of today's society, it is expected that the teachers will have a high level of competence and that there will be a necessary change in the role and tasks of teachers (Bogosavljević, 2013; Bossenz et al., 2020; Flores, 2016; Frost, 2019), and especially development of competences that would ensure successful adaptation to the environment and respond to the demands of society. It would be of great importance that there are prescribed national standards for initial teacher education, shared knowledge, skills and abilities for all the graduated teachers who could acquire this knowledge through compulsory subjects in initial studies (Branković et al., 2014). Such a prescribed, common core is particularly relevant to pedagogical-psychological subjects which, in addition to the methodological knowledge that the future teachers will acquire, would form the backbone of the competences for each teacher's work. High education institutions have autonomy in the choice of subjects and content, but it must be ensured that certain competences are acquired when entering the world of work (Evansa et al., 2017; Gonzales \& Wagenaar, 2006).

Analyzing the relevant scholarly literature, there are numerous definitions and reflections on the competences of teachers that have been the subject of research by many experts, and we can talk about the following "range" of teacher competences, which makes the profile of competences of today's teachers: pedagogical, psychological, subject, didactic-methodological, mathematical, communication, social, emotional, organizational, informatics, civic, intercultural, media, research or scientific competences, competences in working with parents, and children with disabilities (Chivers, 1996; Frost, 2019; Hrvatić \& Piršl, 2007; Jurčić, 2012; Lončarić \& Pejić Papak, 2009; Yahekulovich,2020).

Initial teacher education is a particular challenge for raising the quality of education. The first attempts to address these issues in Serbia were the "The teaching profession and professional development competence standards" (National Education Council), which recognizes the crucial importance of teachers in the overall development of children. These standards are linked to four categories of competences: subject area of teaching, subjects and their didactics, learning and teaching, encouragement of individual development of students, and communication and cooperation with students, parents and colleagues (Common european principles for teacher competences and qualifications, 2005). Each competence is defined in five domains: knowledge, planning, realization, assessment/evaluation and professional development. These competence standards should serve teachers as an occasion to reflect on their own professional work and as a means to monitor and plan their own development. Being obligatory for all the teachers, these standards are also a tool for evaluating their professional work (Vranješević \& Trikić, 2013). Therefore, it is important that the initial education of teachers enables the acquisition of competency standards through compulsory subjects at all faculties. In this research we first want to map the current 
situation from the aspects of pedagogical and psychological subjects and based on the results, to suggest which subjects in these areas should be part of the corre curicculum.

\section{METHOD}

In this paper, we assume that teachers must acquire the basic competences which are required of them when they are entering the world of work, during their initial education. Therefore, the curriculum in basic ( 4 years) and master ( 1 year) studies must be designed in such a way that compulsory subjects allow students to achieve the prescribed teacher competence standards. For the purposes of this paper, we have defined teacher competences as the capacity of an individual expressed in performing complex activities in educational work, or as a set of necessary knowledge, skills and values of teachers. They are determined in terms of learning goals and outcomes; they provide professional standards for teaching that is considered successful. As mentioned, according to this classification competences are divided into:

K1: competences for teaching area, subjects and teaching methodology,

K2: teaching and learning competences,

K3: competences for student personality development support and

K4: communication and cooperation competences.

Within each competence, there are clearly defined standards for particular areas of teacher's work: knowledge, planning, realization, evaluation and improvement (http://katalog.zuov.rs/StandardiKompetencija.aspx). In this paper we have focused on the curricula in the basic and master level of studies and on this division of competences, the fact that the teachers are required to have certain competences and we want to answer the question - to what extent do compulsory subjects in the field of pedagogical and psychological sciences respond to prescribed competence standards.

The paper sets the following goals:

1. to determine whether the content of existing compulsory subjects in all the faculties in these two scientific fields enables students to obtain appropriate teacher competence standards,

2. to determine if there are grounds in the existing curricula in the pedagogical/teacher education faculties to build a "core curriculum" in the field of pedagogical and psychological sciences and to make a proposal for the content of the core curriculum.

An analysis of the documentation on accreditation of pedagogical and teacher education faculties was conducted; particularly the curriculum structures and books of subjects. For the purposes of this research, official documents (a total of 7 curricula) were used, which were taken from the digital platforms of public universities, current in the 2018/2019 academic year. Subjects that can undoubtedly be placed in the field of pedagogical and psychological sciences were analyzed. For the realization of the set goal and research questions, a method of content analysis was used, with which we analyzed the curricula of the faculty for teacher education. The technique of this research is work with documentation, and the instrument is a matrix for document analysis. The sample of the analysis was the entire population, ie all state faculties that 
educate teachers in Serbia. The sample of the analysis was valid curricula in valid accreditation, which are available on the websites of the following state-owned faculties:

1. University of Belgrade, Teacher Education Faculty in Belgrade,

2. University of Novi Sad, Faculty of Education in Sombor,

3. Univesity of Novi Sad, Teacher Training Faculty in the Hungarian Language in Subotica,

4. University of Kragujevac, Faculty of Education in Jagodina,

5. University of Kragujevac, Faculty of Education in Užice,

6. University of Niš, Faculty of Pedagogy in Vranje and

7. University of Priština, Teacher Training Faculty in Leposavić.

The number of subjects, theory and practical exercise classes, the status of the subject, the semester in which the subject is taught and the scientific disciplines of pedagogy and psychology to which the subject belongs were being analyzed.The analysis was done according to the parameters of scientific disciplines of pedagogical and psychological sciences, which could be made available on the basis of available documentation. From the interpretative perspective (Creswell \& Poth, 2018), we presented the available facts by presenting the information. We paid special attention to the content of compulsory subjects present in all the faculties in both scientific fields.

\section{FINDINGS AND DISSUCION}

\section{Analysis of Psychological Subjects}

Compulsory psychological subjects in all pedagogical/teacher education faculties in Serbia are subjects from two fields of psychology: Developmental and Pedagogical psychology (Table 1).

Table 1

Compulsory psychological subjects in all the faculties, semester and number of weekly classes

\begin{tabular}{|c|c|c|c|c|c|c|c|}
\hline & Beograd & Sombor & Vranje & Užice & Jagodina & Subotica & Leposavić \\
\hline $\begin{array}{l}\text { General and } \\
\text { developmental } \\
\text { psychology }\end{array}$ & & & & $\begin{array}{l}\mathrm{I}, \mathrm{II} * \\
2+2 * *\end{array}$ & & & \\
\hline $\begin{array}{l}\text { Developmental } \\
\text { psychology }\end{array}$ & $\begin{array}{l}\mathrm{I} \\
2+1 \\
\end{array}$ & $\begin{array}{l}\mathrm{I} \\
2+2\end{array}$ & $\begin{array}{l}\text { I,II } \\
2+2 \\
\end{array}$ & & $\begin{array}{l}\text { I } \\
2+2 \\
\end{array}$ & $\begin{array}{l}\text { II } \\
2+1\end{array}$ & $\begin{array}{l}\mathrm{I} \\
3+3 \\
\end{array}$ \\
\hline $\begin{array}{l}\text { Pedagogical } \\
\text { psychology }\end{array}$ & $2+1$ & $\begin{array}{l}\mathrm{V} \\
3+3\end{array}$ & $\begin{array}{l}\text { III,IV } \\
2+2 \\
\end{array}$ & $\begin{array}{l}\text { III,IV } \\
2+1\end{array}$ & $\begin{array}{l}\text { IV } \\
2+2\end{array}$ & & $\begin{array}{l}\text { IV } \\
3+3\end{array}$ \\
\hline $\begin{array}{l}\text { Introduction to } \\
\text { pedagogical } \\
\text { psychology }\end{array}$ & & & & & & $\begin{array}{l}\text { III } \\
2+1\end{array}$ & \\
\hline $\begin{array}{l}\text { Educational } \\
\text { psychology }\end{array}$ & & & & & & $\begin{array}{l}\text { IV } \\
2+1\end{array}$ & \\
\hline
\end{tabular}


Among the psychological subjects, the number of theory and practical exercise classes is not uniform, nor is the length per semesters. It is noticeable that there is no such subject, from the field of general psychology, in all the faculties that would enable a more adequate mastery and understanding of content in the field of developmental psychology, especially if the students did not have Psychology as a subject in their secondary schools. Other psychological subjects are also not uniform in all the faculties. There are 29 subjects in total, and they can be classified into several areas of psychology as a science:

1. General psychology: Introduction to psychology, Basic concepts of general psychology, a part of the subject General and developmental psychology,

2. Developmental psychology: Developmental Psychology, a part of the subject General and developmental psychology,

3. Pedagogical psychology: Introduction to pedagogical psychology, Pedagogical psychology, Educational psychology, Teaching and learning in contemporary school, Psychology in education, Strategies for successful learning, Individualization and support for students in educational work, Motivation of students living in adverse conditions,

4. Personality psychology: Personality psychology,

5. Psychology of giftedness: Working with gifted children, Working with gifted students, Psychology of giftedness,

6. Psychology of communication: Psychology of communication, Constructive conflict management, Communication methods, Constructive conflict solving, Interaction and communication in education,

7. Mental hygiene: Psychological counseling, Mental health, Psychological counseling in educational work, Psychology of mental health,

8. Interdisciplinary field: Childhood and children's rights, Psychological practicum, Psychopathology, Clinical psychology: Psychology of children with special needs, Specific development and learning disabilities.

An overview of the subjects in the field of psychological sciences in the faculties is given in Table 2. 
Table 2

Psychological subjects in the faculties

\begin{tabular}{|c|c|c|c|c|c|c|c|}
\hline 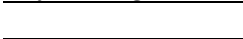 & Beograd & Sombor & Jagodina & Užice & Vranje & Leposavić & Subotica \\
\hline $\begin{array}{l}\text { General } \\
\text { psychology }\end{array}$ & + & & & + & & & + \\
\hline $\begin{array}{l}\text { Developmental } \\
\text { psychology }\end{array}$ & + & + & + & + & + & + & + \\
\hline $\begin{array}{l}\text { Pedagogical } \\
\text { psychology }\end{array}$ & + & + & + & + & + & + & + \\
\hline $\begin{array}{l}\text { Personality } \\
\text { psychology }\end{array}$ & + & & & & & & \\
\hline $\begin{array}{l}\text { Psychology of } \\
\text { giftedness }\end{array}$ & + & & + & & + & + & \\
\hline $\begin{array}{l}\text { Psychology of } \\
\text { communication }\end{array}$ & + & & + & + & + & & \\
\hline $\begin{array}{l}\text { Psychopathology, } \\
\text { Clinical } \\
\text { psychology }\end{array}$ & & + & & & + & & \\
\hline Mental hygiene & + & + & + & & + & & \\
\hline $\begin{array}{l}\text { Interdisciplinary } \\
\text { field }\end{array}$ & & + & + & & & & \\
\hline
\end{tabular}

If we look at the current situation from the aspect of the construction of the future core curriculum, we can conclude that the core of psychological knowledge in the curriculum consists of subjects in the field of developmental and pedagogical psychology. They are present in all the faculties and they are compulsory for all the students. We will try to determine whether the content of these two psychological subjects enable future teachers to acquire the prescribed competence standards in Serbia. The content of theoretical and practical lessons of these two compulsory subjects will be analyzed from the aspect of particular competence standards.

Regarding the standard of competences for teaching area, subjects and teaching methodology $(K 1)$, psychological subjects do not have a role in their acquisition and will not be considered here.

Teaching and learning competences (K2) are closely linked to the two main compulsory subjects. Within the certain areas of competence standards, we can identify areas of one or the other branch of psychology. By examining the content of theoretical and practical lessons and bearing in mind the theoretical and methodological character of the subject, we can see that the content in the field of developmental and educational psychology correspond only to the standards of knowledge, and not the standards of planning and realization.

Competences for student personality development support (K3) present a domain where the most important role is played by the subjects in the field of psychological sciences. These subjects are not compulsory in the faculties, and cannot be found in all the faculties even as the optional subjects. Therefore, it is questionable how the students 
will acquire the necessary competences to work in the classroom, because only the subjects in the field of personality psychology and mental health/mental hygiene can provide a basis for achieving $K 3$ competence standards. An overview of $K 2$ and $K 3$ competence standards fulfillment is provided in Table 3.

Table 3

Competence standards for learning and teaching (K2) and for student personality development support (K3)

\begin{tabular}{lll}
\hline K2 & Developmental psychology & Pedagogical psychology \\
knowledge & $\begin{array}{l}\text { cognitive development, zone of proximal } \\
\text { development, nature of thinking, }\end{array}$ & $\begin{array}{l}\text { formation of scientific concepts, } \\
\text { nature of learning, learning styles, } \\
\text { learning strategies }\end{array}$ \\
\hline$K 3$ & $\begin{array}{l}\text { knowing and understanding physical, emotional and social differences among the } \\
\text { students, knowing the psychological, emotional and social development of } \\
\text { students, knowing the motivation and the way of motivating students, stimulating } \\
\text { the development of all the capacities respecting the individuality of students }\end{array}$ \\
\hline
\end{tabular}

The $K 2$ competence standards in the field of knowledge in both subjects are largely fulfilled. Developmental and pedagogical psychology deal with the knowledge of students' personalities and individual differences, but only in a general way. The subjects lack content that meets the following competence standards: he/she knows and understands cultural differences among the students, knows the ways to support students from vulnerable groups, activities to engage all the students respecting the individual differences among them, applies procedures to encourage students' self-esteem and selfrespect, encourages students' creativity and initiative, interaction of all the students is based on the respect for diversity, implements the procedures for constructive solving of development problems, crises and conflicts, provides opportunities and environment for students' activities, interests and needs respecting their attitudes and opinions, fosters self-esteem and self-respect. We would like to emphasize that the compulsory content in the subjects in the field of pedagogical psychology should be school and classroom climate, the ways of managing teaching and students.

Communication and cooperation competences $(K 4)$ are represented in the minimum number of compulsory subjects in the field of developmental and pedagogical psychology. The optional subjects are mostly dedicated to building these competences. If the students do not choose them, they will not acquire the necessary knowledge and skills for a significant aspect of the teacher's work. We emphasize the knowledge and skills needed for communication and cooperation with parents, which should certainly find their place in the structure of the core curriculum in the field of psychological sciences. Within this competence, psychological subjects could respond to the following subjects and standards of knowledge: he/she has knowledge of successful communication techniques and knows the forms and content of cooperation with different partners (Kodžopeljić \& Pekić, 2017).

\section{Analysis of Pedagogical Subjects}

In the study programs of the faculties in Serbia, where teachers are being educated, there is a difference in the number of pedagogical subjects, the number of weekly classes, and 
in the status of the subject (whether they are compulsory or optional ones). An overview of the subjects is provided in Table 4 .

Table 4

Compulsory pedagogical subjects in all the faculties, semester and number of weekly classes

\begin{tabular}{|c|c|c|c|c|c|c|c|}
\hline & Beograd & Sombor & Vranje & Užice & Jagodina & Subotica & Leposavić \\
\hline \multirow{2}{*}{$\begin{array}{l}\text { General } \\
\text { pedagogy }\end{array}$} & $\mathrm{I}^{*}$ & $\mathrm{I}$ & I & I,II & II & I,II & II \\
\hline & $2+1 * *$ & $2+2$ & $3+2$ & $2+1(2)$ & $2+2$ & $2+1(2)$ & $2+4$ \\
\hline \multirow[t]{3}{*}{ Didactics } & IV & IV & III,IV & I,II & III,IV & III,IV & III \\
\hline & $2+2$ & $3+2$ & $2+2(2)$ & $3+2(2)$ & $2+2(2)$ & $2+2$ & $4+4$ \\
\hline & & & & & & $2+1$ & \\
\hline \multirow{2}{*}{$\begin{array}{l}\text { Methodology of } \\
\text { pedagogical } \\
\text { research }\end{array}$} & III & VIII & $\mathrm{V}, \mathrm{VI}$ & $\mathrm{V}, \mathrm{VI}$ & IV & - & $\mathrm{V}$ \\
\hline & $1.5+1$ & $2+1$ & $2+2(2)$ & $2+1(2)$ & $2+1$ & & $2+0$ \\
\hline \multirow[t]{2}{*}{ School pedagogy } & $\mathrm{V}$ & - & IV & $\mathrm{V}$ & - & VI & $\mathrm{V}$ \\
\hline & $1+0,5$ & & $2+1$ & $2+2$ & & $2+1$ & $2+0$ \\
\hline \multirow[t]{2}{*}{ Family pedagogy } & $\mathrm{V}$ & - & $\mathrm{V}$ & VI & - & $\mathrm{V}$ & VI \\
\hline & $1+1,5$ & & $2+1$ & $2+2$ & & $2+1$ & $2+1$ \\
\hline $\begin{array}{l}\text { School and } \\
\text { family pedagogy }\end{array}$ & - & $\begin{array}{l}\text { II } \\
2+2\end{array}$ & - & - & $\begin{array}{l}\mathrm{V} \\
4+2\end{array}$ & - & - \\
\hline
\end{tabular}

* semester; ** number of weekly classes

Based on the analysis, it can be concluded that General pedagogy is taught as a compulsory subject in all the faculties with different number of classes. The analysis of plans and programs indicates that Didactics is taught in all the faculties as a compulsory subject, with different number of classes. The subject that is the same in all the teacher education faculties is Methodology of pedagogical research, and it is studied everywhere as a compulsory subject, except in Subotica where this subject is optional. The field of pedagogical science that is taught in all the faculties, as a compulsory subject, but with the greatest diversity is School and family pedagogy. In some faculties, these subjects are taught as one compulsory subject, during one semester with a different number of classes. In other faculties, it is taught separately - as two subjects, usually in the third year. We think that it would be of great importance for future teachers to study these subjects separately because of their extensive and varied content.

A large number of optional subjects is offered in all the faculties. The total number of optional subjects is listed in Table 5. 
Table 5

Optional subjects and pedagogical disciplines in the faculties

\begin{tabular}{|c|c|c|c|c|c|c|c|}
\hline & $\begin{array}{l}\text { Beograd } \\
(5)\end{array}$ & $\begin{array}{l}\text { Sombor } \\
(3)\end{array}$ & $\begin{array}{l}\text { Vranje } \\
\text { (9) }\end{array}$ & $\begin{array}{l}\text { Užice } \\
(6)\end{array}$ & $\begin{array}{l}\text { Jagodina } \\
(3)\end{array}$ & $\begin{array}{l}\text { Subotica } \\
(5)\end{array}$ & $\begin{array}{l}\text { Leposavić } \\
\text { (5) }\end{array}$ \\
\hline $\begin{array}{l}\text { Docimology } \\
\text { and assessment }\end{array}$ & + & & & + & & + & + \\
\hline $\begin{array}{l}\text { History of } \\
\text { pedagogy } \\
\text { (fields of } \\
\text { pedagogy) }\end{array}$ & + & & + & + & + & & + \\
\hline Andragogy & & & + & + & & + & + \\
\hline $\begin{array}{l}\text { Specific areas } \\
\text { of work } \\
\text { (organization) }\end{array}$ & + & + & + & + & + & + & + \\
\hline Other & & + & & + & + & & \\
\hline
\end{tabular}

The analysis showed that there is a relatively uniform list of compulsory subjects in the faculties, but there is a difference in the list of optional ones. There is a specific autonomy towards various offerings and the fields of pedagogical science. An attempt was made to analyze which pedagogical field has the largest number of optional subjects.

1. Docimology and assessment: Docimology, Introduction to docimology,

2. History of pedagogy (field of pedagogy-pedagogical discipline): History of pedagogy, Comparative pedagogy, Action research, Preschool pedagogy, Special pedagogy, Leisure pedagogy.

3. Andragogy: Introduction to andragogy, Andragogy, Education of vulnerable groups of adults.

4. Specific areas of work (organization): Methodology of work in combined classes, Work in combined classes, Organization (methodology) of work in extended and fullday stay, Methodology of additional classes for slow and talented students, Organization of visits and school trips-practicum, Working as a form teacher, School in nature, Cooperation between parents and school, Working with talented children (students),

5. Other: Didactic games, Education systems, Education system in the Republic of Serbia,

We can conclude that if we look at the current situation from the perspective of the core curriculum, the list of optional subjects is different, but the fourth category - Specific area of work (organization) contains the largest number of optional subjects that affect the creation of further professional competences. In the further analysis, we will try to determine whether these, compulsory subjects, all five of them, from the pedagogical group of subjects, enable future teachers to acquire competence standards.

When it comes to the standards of competences for teaching area, subjects and teaching methodology, pedagogical subjects have a significant role in their acquisition, especially General pedagogy: the goals and outcomes of studying within the educational work, basic characteristics of personality development; and Didactics: syllabus, curriculum 
and teaching technology, didactic-methodical knowledge (didactic principles, teaching methods, students' activities in classes, indicators of quality of work).

Teaching and learning competences (K1) are closely linked to the five main compulsory subjects. The standards for knowledge, planning and realization, assessment/evaluation and improvement will be mentioned in the text below without clear demarcation. General pedagogy: different ways of work for achieving the goal and the tasks of education through socio-historical conditionality of education, different questions and ideas, discussion and comments; Specificity of educational work with young children (and School pedagogy); Didactics: education, the concept and its importance in teaching; teaching, teaching tasks and structure of the teaching process, development of learning strategy; School and family pedagogy: using different ways of work and activities according to the characteristics of the students, encouraging different learning styles and strategies (evaluation and assessment procedures), Ability to think analytically and critically about the importance and role of the family.

The content of General pedagogy and Didactics is mostly present, while the content of Family pedagogy and Methodology of pedagogical research is least present.

Competences for student personality development support is the competence in which subjects from the group of pedagogical sciences play the largest role. General pedagogy: he/she understands student development, School and family pedagogy: pedagogical skills for class management, respects the interests and needs of students by accepting their views and opinions, cooperation with other students and parents.

It cannot be found in the syllabuses (or it is not explicitly stated), but it should be noted within the scope of this competence - he/she plans interaction of all the participants in the educational work based on respect for diversity and respecting their needs. It is noticeable that the most content from the third competence covers the field of school pedagogy and the least didactics and methodology of pedagogical research.

Communication and cooperation competences are mostly represented through the subjects of School pedagogy (School and family pedagogy) and Family pedagogy: understanding the importance and significance of cooperation with parents, the ways and content of cooperation between family and school, planning of cooperation with parents and other partners, team work analysis, Didactics: teamwork training as different way of teaching. The syllabuses of the main compulsory subjects lack the content related to communication skills and they should be represented within this competence.

Pedagogical subjects are represented in all the competences, especially in teaching and learning competences and competences for support and cooperation, the first competence is less represented as it relates to the teaching area (pedagogy provides a part concerning the teaching methodology) and the least represented is the acquisition of competences for student personality support. The content which should be added to meet the competence standards are about respecting diversity and developing interculturalism. There is also a lack of content that enhances communication skills in the fourth competence. 


\section{CONCLUSION}

The fields of theory of education, pedagogy, pedagogical psychology, developmental psychology and legal issues in education must be represented in the subjects and modules in the teacher education faculties (Bossenz et al., 2020). School practice must be integrated into the program, under controlled conditions, with mentoring and supervision. Knowledge in particular areas of the curriculum should be added to this (Teacher Education Policy in Europe Conference, 2008). It is desirable to enrich the programs with new areas, such as education for interculturalism and the application of information and communication technology. As teacher education has consolidated its position in master studies, and for the needs of the profession, competences in the field of scientific research need to be enhanced. This would expand the knowledge about learning, teaching and related interdisciplinary fields.

By mapping the current situation in the field of psychological subjects in the initial teacher education in Serbia, we come to the conclusion that there is a basis for the core curriculum in the field of psychology, and these are Developmental and Pedagogical (educational, school) psychology. One subject belongs to the fundamental and the other to the applied psychological disciplines. From the aspect of teacher education, Developmental psychology and Pedagogical psychology belong to the theoreticalmethodological group of subjects (Ingvarson \& Rowe, 2007; Šimonji Černak \& Mićanović-Cvejić, 2018). The standards of teacher competencies imply a deep understanding of development, learning, motivation and individual differences between students. Therefore, the contents of both of these subjects present the basis for understanding the development lines in the psychological capabilities of children (physical and motorical development, intelligence development, observation, perception, personality development, speech and language development, methods of reserach in psychology...) and for the application of psychological knowledge in the processes of upbringing and education (theories and forms of learning, motivation, assessment and evaluation, teacher characteristics, the origin of individual differences in the classroom ...). Beside these two subjects, compulsory psychological subjects that would be in the core curriculum should also include General psychology or Introduction to psychology. The reason for this is that most of the students at the pedagogical faculties have graduated from a secondary school that did not have Psychology as a subject, which would give them at least minimal knowledge. The best solution is to have General psychology in the first year of studies, Developmental psychology in the second and Pedagogical psychology in the third year.

Content of both theoretical and practical lessons in existing compulsory subjects should be supplemented to meet competence standards for student personality development support (encouraging self-esteem and self-confidence, support for students from vulnerable groups) and communication (teacher-student interaction, managing the classroom and classroom conflicts, classroom climate). Psychological subjects have the most important role in acquiring knowledge about the personality of students and teachers (Bossenz et al., 2020; Flores, 2016). Therefore, this content could be part of 
educational psychology. The competence standards for learning and teaching in the field of knowledge have been accomplished almost completely.

The core curriculum can contribute to a clear and unambiguous opportunity for the teacher to acquire all the necessary competences for further work (D'Elia et al., 2018; Kuiper \& Berkvens, 2013). By mastering the study program, the student acquires general and subject-specific abilities needed to professionally do the job for which he/she was educated. Having the pedagogical and psychological subjects in mind, the core curriculum contributes to a clearer picture of compulsory and optional pedagogical and psychological subjects, which will contribute to an equal competence basis before entering the labor market. Later, through professional development, experience, attending various seminars, relying on scholarly literature, in communication with colleagues, the teachers will improve their competences and strengthen themselves in their further work.

The proposal for the core curriculum for pedagogical sciences would certainly consist of the basic subjects that are actually taught in all the faculties. It should include these five subjects: General pedagogy ( $1^{\text {st }}$ year $)$, Didactics $\left(2^{\text {nd }}\right.$ year $)$, School pedagogy $\left(3^{\text {rd }}\right.$ year $)$, Family pedagogy ( $3^{\text {rd }}$ year) and Methodology of pedagogical research ( $4^{\text {th }}$ year $)$. There is a large incompatibility within these subjects as they are already present in the faculties, but with different names and number of weekly lessons and they are taught during different semesters. Optional subjects are the biggest problem in the faculties where future teachers are being educated. Within the core curriculum, it would be good to study optional subjects from each proposed area (there are five of them in totalHistory of pedagogy, Work organization, Andragogy, Education system and Docimology). Such a core curriculum within the pedagogical group of subjects would enable the acquisition of competences for successful and quality performance of the complex role of the teacher in primary education.

A unified proposal for the core curriculum in the field of psychological and pedagogical sciences is shown in Appendix. These would be the compulsory subjects that should be present in all the teacher education faculties. Psychological subjects develop from General psychology, through Developmental psychology and they end with Pedagogical psychology. General psychology presents the introduction to psychology and the goal of the subject is for students to adequately use basic psychological terms, which will make their comprehension of further psychological subjects easier. The outcome of Developmental psychology can be briefly described as training students to understand the concept of development and developmental changes in various aspects of development. The goal of Pedagogical psychology is understanding the application of scientific knowledge from psychology to the educational process. In this way, subjects move from general to a specific knowledge that is necessary for teachers. The situation is to a certain extent the same when it comes to pedagogical subjects. The most important terms, the introduction to pedagogy would have been represented within the subject General pedagogy in the first year, then Didactics in the second year where students would get familiar with teaching systems, contents and processes significant to their future work. In the third year, students would deal with School pedagogy and 
Family pedagogy so that in the fourth year, they would study Methodology of pedagogical studies. Thus, students would have basic pedagogical knowledge and a solid basis to study optional subjects and continue their education. Likewise, they would acquire inevitable, complex pedagogical competencies for teacher work in today's society.

\section{REFERENCES}

Bogosavljević, R. (2013). Od učitelja predavača do učitelja profesionalca [From preservice teacher to professional teacher]. Novi Sad: Pedagoško društvo Vojvodine.

Branković, J., Kovačević, M., Stensaker, B., Maassen, P., \& Vukasovic, M. (eds.). (2014). The re-institutionalization of higher education in the Western Balkans: the interplay between European ideas, domestic policies, and institutional practices. Higher Education Research and Policy. Frankfurt am Main: Peter Lang.

Bossenz,H.L., Westphal, A. \& Vock, M. (2020). Pedagogical and Psyhological content in teacher education. In: Thomas Lehmann (ed): International Perspectives on Knowledge Integration: Theory, Research, and Good Practice in Pre-service Teacher and Higher Education, pp.181-201

Common european principles for teacher competences and qualifications, (2005). From https://ec.europa.eu/education/policies/2010/doc/principles_en.pdf 4

D'Elia, F., Mazzeo, F.,\& Raiola, G. (2018). The core curriculum in the university training of the teacher of physical education in Italy. Journal of Human Sport and Exercise, 13(2), 413-420. doi: https://doi.org/10.14198/jhse.2018.13.Proc2.25

Domović, V. (2009). Planiranje kurikuluma usmerenog na kompetencije u obrazovanju učitelja $i$ nastavnika [Curriculum planning focused on competencies in teacher education]. Zagreb: Filozofski fakultet.

Chivers, G. (1996). Towards a holistic model of professional competence, Journal of European Industrial Training, 20(5), 20-31.

Creswell, J. W., \& Poth, C. N. (2018). Qualitative inquiry and research design (4th ed.). Thousand Oaks, CA: Sage Publications.

Evansa, N., Stevensona R., Lasena M., Ferreira, J. \& Davisc, J. (2017). Approaches to embedding sustainability in teacher education: A synthesis of the literature. Teaching and Teacher Education, 63, 405-417. https://doi.org/10.1016/j.tate.2017.01.013

Fallows, S., \& Steven, C. (eds) (2000). Integrating Key Skills in Higher Education. London: Kogan Page.

Flores, M.A. (2016). Teacher Education Curriculum. In: J., Loughran, M., Hamilton (eds). International Handbook of Teacher Education. Springer, Singapore. https://doi.org/10.1007/978-981-10-0366-0_5 
Frost, D. (2019). Osnaživanje nastavnika kao nosioca promena: neformalizovan pristup liderstvu nastavnika, [Empowering Teacher as Agents of change: a non-positional approach to teacher leadership]. Beograd: Centar za obrazovne politike.

Gonzales, J., \& Wagenaar, R. (eds.) (2006). Tuning Educational Structures in Europe: Universities' Contribution to the Bologna Process-an introduction. Socrates-Tempus.

Hrvatić, N., \& Piršl, E. (2007). Kurikulum pedagoške izobrazbe učitelja [Teacher Education Curriculum]. In V. Previšić (Ed.), Kurikulum: Teorije, metodologija, sadržaj, struktura (pp. 385-407). Zagreb: Zavod za pedagogiju; Školska knjiga.

Ingvarson, L., \& Rowe, K. (2007). Conceptualising and Evaluating Teacher Quality: Substantive and methodological issues, Australian Journal of Education, 52(1), 1-25.

Jurčić, M. (2012). Pedagoške kompetencije suvremenog učitelja [Contemporary teacher's pedagogical competencies]. Zagreb: Recedo.

Katalog programa stalnog stručnog usavršavanja nastavnika. [Catalog of continuing professional development programs for teachers]. Retrieved 15 November, 2019 from http://katalog.zuov.rs/StandardiKompetencija.aspx.

Kodžopeljić, J., \& Pekić, J. (2017). Psihologija u nastavi [Psychology in teaching]. Novi Sad: Filozofski fakultet.

Kosová, B., Tomengová, A., Duchovičová, J., Doušková, A., Šveda, D., Portik, M., Pavlov, I., Petrasová, A., Kmet’ová, J., Valachová, D., Fridrichová, P. (2015). Profesijná príprava budúcich učitel'ov [Vocational training of future teachers]. Banská Bystrica: Pedagogická fakulta.

Kuiper, W., \& Berkvens, J. (eds.) (2013). Balancing curriculum regulation and freedom across Europe. Enschede: CIDREE Yearbook 2013.

Lončarić, D., \& Pejić Papak, P. (2009). Profiliranje učiteljskih kompetencija [Profiling teacher competencies]. Odgojne znanosti, 11(2), 479-497.

Pravilnik o planu nastave i učenja za prvi ciklus osnovnog obrazovanja i vaspitanja i programu nastave i učenja za prvi razred osnovnog obrazovanja i vaspitanja (2017). [Rulebook on the curriculum for the first cycle of primary education] Sl. glasnik RS Prosvetni glasnik", br. 10/2017

Strategija razvoja obrazovanja u Srbiji do 2020.godine [Education development strategy in Serbia until 2020] (2012). Sl.glasnik Republike Srbije broj 107/2012.

Šimonji Černak, R., \& Mićanović Cvejić, Ž. (2018). Psihološki predmeti i kompetencije budućih učitelja [Psychological subjects and competencies of future teachers]. Pedagoška stvarnost, $\operatorname{LXIII(2),~158-170.~}$

Teacher Education Policy in Europe (TEPE) Conference (2008). Official Conference Document Conclusions and Recommendations. Ljubljana: University of Ljubljana. 
Vranješević, J., \& Trikić, Z. (2013). Kompetentan nastavnik/ca u kompetentnom sistemu-Srbija [Competent teacher in a competent system-Serbia]. In V. Vizek-Vidović, \& V. Velkovski, Z. (eds.), Nastavnička profesija za 21.vek-Unapređenje nastavničke profesije za inkluzivno, kvalitetno $i$ relevantno obrazovanje-ATEPIE (pp. 60-64). Beograd: Centar za obrazovne politike.

Vukasović, M. (2006). Razvoj kurikuluma u visokom obrazovanju [Curriculum development in higher education]. Beograd: Alternativna akademska obrazovna mreža.

Plan rada sekcije unverzitetskih nastavnika psihologije obrazovanja [Work plan of the section of university teachers of education psychology], (2018) Retrived 12.11.2019. from http://dps.org.rs/o-drustvu-psihologa/sekcije/73-sekcija-univerzitetskih-nastavnikapsihologije-obrazovanja

Yahekulovich, K. N. (2020). The problem of Developing a Teacher's Creative Competence as a Subject of Pedagogical Research. European Journal of Research and Reflection in Educational Sciences, 8(8), 100-106. www.idpublications.org

\section{Appendix}

Table 1

Proposal of psychological-pedagogical core curriculum

\begin{tabular}{|c|c|c|c|c|c|c|c|}
\hline Psychological & stat. & sem. & classes & Pedagogical & stat. & sem. & classes \\
\hline $\begin{array}{l}\text { General } \\
\text { psychology }\end{array}$ & $\mathrm{C}$ & 1 & $2+2$ & General pedagogy & $\mathrm{C}$ & 1 & $2+2$ \\
\hline $\begin{array}{l}\text { Developmental } \\
\text { psychology }\end{array}$ & $\mathrm{C}$ & 3 & $2+2$ & Didactics & $\mathrm{C}$ & 3 & $2+2$ \\
\hline \multirow{3}{*}{$\begin{array}{l}\text { Educational } \\
\text { psychology }\end{array}$} & \multirow[t]{3}{*}{$\mathrm{C}$} & \multirow[t]{3}{*}{5} & \multirow[t]{3}{*}{$2+2$} & School pedagogy & $\mathrm{C}$ & 5 & $2+1$ \\
\hline & & & & Family pedagogy & $\mathrm{C}$ & 6 & $2+1$ \\
\hline & & & & $\begin{array}{l}\text { Methodology of } \\
\text { pedagogical research }\end{array}$ & $\mathrm{C}$ & 7 & $2+2$ \\
\hline
\end{tabular}

